\title{
Gender in Students' Achievement in English Essay Writing Using Collaborative Instructional Strategy
}

\author{
Okonkwo Adaobi Fidelia \\ Arts and Social Science Education Department \\ Faculty of Education \\ Ebonyi State University, Abakaliki \\ Tel:08035401195 E-mail: okonkwoclem@yahoo.com
}

Received: February 13, 2014 Accepted: December 5, 2014 Published: December 10, 2014

doi:10.5296/ijele.v3i1.6763 URL: http://dx.doi.org/10.5296/ijele.v3i1.xxx

\begin{abstract}
This study investigated the effects of gender using collaborative instructional strategy on students' achievement in English essay writing. The design is a quasi experimental study of pretest post test non equivalent control group design. The sample of the study was 191 SS 2 students in four co-educational secondary schools in Abakaliki urban schools with population of 1,797 students. The instrument used was EEAT achievement test. Two groups of students were taught using collaborative instructional strategy for experimental group and the conventional method was used for control group. Mean and standard deviation were used to analyse the research question while ANCOVA analysis of covariance was used to test the hypothesis at an alpha of 0.05 level of significant. Results obtained indicated that males performed better than females in the experimental group but females performed better than males in the control group. Test of significance showed no significance. Hence, the hypothesis was accepted. The educational implications were that sex is not a barrier to attainment of a students' desire in education. Instructional strategy that is gender sensitive but yields effective result for both sexes should be used with caution so that it will benefit both sexes.
\end{abstract}

Keywords: Collaboration, Gender, Strategy, Achievement, Essay Writing 


\section{Introduction}

Essay writing is a fundamental skill of art. It is a skill which demands that students should organize their thoughts clearly and effectively. Hornby (2004) sees writing as the activity of writing in contrast to reading. Azikiwe (1998) observes that writing a long essay is probably the most complex constructive art that most human beings are ever expected to study. Ghaith (2006) sees essay writing as a complex process that allows writers to explore thoughts and ideas and make them visible and concrete. Essay writing constitutes an aspect of the English language called composition. It is an aspect of writing that has its non peculiarity and distinctly, its own techniques. Banjo and Bisong (2005) identify qualities of good essay as grammatical accuracy, unity topic sentence and coherent.

Students are expected to be grounded in all these. Essay writing is an important part of the English language, which is taught in both junior and senior secondary schools. The students cannot do without essay in the language learning process. The Federal Republic of Nigeria in the National Curriculum for Senior Secondary Schools' English (2004:1) states that the curriculum is designed to achieve a high level of proficiency in the Nigeria students' use of the English language, preparing students for tertiary and vocational education; for the world of work after learning school. Students performed poorly in essay writing as was confirm by the WAEC Chief Examiner's report 2006.

Collaborative instructional model can be used instead of complete use of the conventional method of teaching. Conventional method of teaching has seen widely criticized because of its obvious limitations. This is because students are made passive listeners and resort to copying long notes as they are being dictated by the teachers (Salani, 2007).

Collaborative instructional strategy is that strategy as proposed by Tinzmann, Jones, Bakka, Fine and Pierce in Ghaith (2006) explain that it is that type of instruction that involves instructor(s) and groups of students working together to maximize learning. Learners have a common goal and attain their goal through collaboration and inter-dependence with one another. The strategy is all embracing and accommodates every student irrespective of his/her academic background. Collaborative instruction provides in-depth learning, involving students in real world relevant tasks and engage in holistic tasks and utilize students' prior knowledge. Collaboration enables students to dialogue and examines different perspectives that make students become knowledgeable strategic, self determined and emphatic (Cohen, 1986). More over, involving students in real-world tasks and thinking new information to prior knowledge requires effective communication and collaboration among teachers, students and others. It is through dialogue and instruction that curriculum objective come to life.

\section{Gender and Students' Achievement}

The issue of gender has remained a controversial issue as to whether it influences students' academic achievement or not. There is the belief that boys are more intelligent than girls and perform well in academics. This may also affect students' performance in essay writing. Kilosmeive and Wilesman in Obioma (2006) reports significant high performance of girls in 
divergent thinking while boys were found to be higher in convergent thinking. This means that boys are likely to make mistakes in their writing, which requires divergent thinking than their female counterparts. Oyetunde in Odo (2004) argues that it may be an over statement to assert that there is a significant disparity in the performance of male and female students in essay writing in English language. He reveals that many institutions of learning enroll more boys than girls. He explains that this may be traced to the fact that more male students go to the science -based disciplines while the female students place more interest in arts of which English language is one. Hutt (2001) states that girls use longer sentences and are better in writing essays and in language than boys but as they grow into adults, the reverse becomes the case as boys, due probably, to the kind of activities they engage, in the process of socialization and growing up, develop their verbal skills.

De Angelis in Okonkwo (2008) views that little boys and most adult men are less verbal than little girls and women because of the differences in their brain and are likely to perform better in language. This may likely affect their essay writing. King in Odo (2004) observes that men are physically strong, less resilient, have greater spatial numerical and mechanical abilities than women and view the world in terms of objects, ideas and theories while women mature physically and psychologically at an earlier age, have higher precocious verbal skills and see the world in personal aesthetic and moral terms. He points to the fact that females may as well perform better in writing than boys.

Some other studies have shown no significance in the performance of males and females in essay writing and in the English language. Radin (1991), Balarabe (1994) and Bodunde (2001) found no sex difference in motivation, learning and performance in language and in essay writing.

Collaborative instruction in the present would be used to investigate the position of gender in achievement in English essay writing.

\section{Statement of Problem}

This study sought to determine the relative effect of gender on students' achievement in English essay writing using collaborative instructional strategy in Abakaliki Urban of Abakaliki Education Zone.

\section{Research Question}

What is the effect of collaborative instructional strategy on the mean achievement score of male and female students taught English essay writing using collaborative instructional strategy?

\section{Hypothesis}

Ho: There is no significant difference in the mean achievement score of male and female students taught essay writing in English using collaborative instructional strategy.

\section{Methodology}

The study was quasi-experimental research designed to investigate effect of gender on 
students achievement in English essay writing using collaborative instructional strategy. it is quasi experiment in the sense that intact classes were used.

The study was carried out in Abakaliki Urban of Abakaliki Education Zone. There are ten secondary schools with seven co-educational schools in this area. All the nine co-education schools' students in SS 2 classes were used. The population constitutes 1,797 and out of this number, a total number of 191 students were sampled. Intact classes of four secondary schools were selected through simple random sampling technique. The four schools that were selected for this study were grouped into two through simple balloting. A total of four schools were selected, two were used for experimental group, the other two were used as control group. Instructional package was prepared for each group, collaborative instructional package was used to teach the experimental group while conventional package was used to teach the control group. The instructional packages and instructional materials were handed to the teachers of each group who serve as research assistants. A training programme was organized for them which lasted for two weeks.

The instrument used was the English Essay Achievement Test (EEAT). This consists an essay question. The essay question was validated by experts in the Ebonyi State University from the Arts and Social Science Education and the Science Education Departments. Reliability of the instrument was also tested. The EEAT instrument was administered to 25 students that were not part of the study and the same question was administered again after two weeks. Data from the two sets of scores were correlated using Pearson Product Moment Correlation in a test retest. A reliability coefficient of 0.890 was obtained which showed a high stability of item and high consistency of the instrument.

At the on set of the experiment pre-test was given and after giving the treatment post test was administered. The experiment lasted for six weeks.

\section{Results}

\section{Research Question}

What is the effect of collaborative instructional strategy on male and female students' achievement in English essay writing?

Table 1 above reveals that among students exposed to the essay writing achievement test in the experimental group, males performed better than females. Males had a mean score of 43.08 and standard deviation of 12.48, while females had a mean score of 40.86 and standard deviation of 15.14. Females in the experimental group performed better than males in the control group. Females in the experimental group had a mean score of 40.86 and standard deviation of 15.14 while males in the control group had a mean score of 31.24 and standard deviation of 14.26. However, females in the control group performed better than males in the same group. Females had mean score of 34.91 with standard deviation of 10.67 while males had a mean score of 31.24 and standard deviation of 14.26. Generally, collaborative instructional strategy was more beneficial than the conventional teaching method.

There is no significant difference in the mean achievement score of male and female students 
taught essay writing in English using collaborative instructional strategy.

Table 2 shows that F.cal at 1.109 is less than $\mathrm{f}$ value of 3.84 . Therefore gender had no significant effect on the achievement score of students taught English essay writing using collaborative instructional strategy. The hypothesis is therefore accepted.

\section{Discussion}

\section{Effect of Collaborative Instructional Strategy on the Mean Achievement Score of Male and Female Students in English Essay Writing}

Results in Table 1 indicate that;

1. Males in the experimental group performed better than females in the same group.

2. Females in the experimental group performed better than males in the control group.

3. Females in the control group performed better than males in the control group.

Results presented in Table 1 indicate that males performed better than females in the overall result. Test of significant difference in Table 1, reveals that the f-value at 1.109 is greater than the f-calculated of .294. Hence, hypothesis 1 is accepted which states that, there is no significant difference in the mean achievement scores of male and female students taught English essay writing using collaborative instructional strategy. The result is at variance with Janet (1996) and Eze (2004) who state that girls develop better attitude to language and communication especially in essay writing, and as a result perform better than boys. The result also disagrees with Umeanyo (2003) who carried out research on error associated with verbs in English using written composition. He discovers that girls commit more errors than boys. However, the above results which indicate that males performed better than females in the experimental group, but females in both groups performed better than boys in the control group does not indicate gender but mainly the instructional strategy adopted. This view is in line with Ushi (2005) who posits that, the fact that girls perform better than boys or boys perform better than girls does not indicate gender.

\section{Conclusion}

Males exposed to treatment using collaborative instructional strategy performed better than males in the control group. Females in the control group performed better than males in the control groups. A test of significance showed no significant effect. This shows that good performance in any subject does not depend on sex but it depends mostly on effective instruction used. This means that students should always be exposed to with caution to instructional strategy that has effect so that it will benefit both sexes.

\section{Recommendations}

1. Instructional strategy that is gender sensitive should be used with caution in teaching students. 
2. Parents, guardians and teachers should encourage their children, wards and students to do those subjects they have interest in. Gender should not determine one's choice in education and other activities.

\section{References}

Azikiwe, U. (1998). Language teaching and learning. Onitsha: African Fep. Publishers Ltd.

Balarebe, M. (1994). Motivation, learning and performances among Nigeria students. $A$ seminar Paper Presented in Faculty of Education. Zaria Ahmadu Bello University.

Banjo, A., \& Bisong, J. O. (2005). Developmental English. Ibadan Spectrum books Ltd.

Bodunde, H. A. (2001). Sex performance in English and communication skills in vocational technical schools. In D.N. Eze (ed) journal of quality education. Owerri: African Publishing Co.

Federal Republic of Nigeria. (2004). National curriculum for senior secondary English. Abuja. NRDC. Press.

Hutt, C. (2001). "Sex does make a difference". The times educational supplement.

Cohon, E. G. (1986). Designing group work: Strategies for the heterogeneous classroom. New York: Teachers College Press.

Ghaith, G. (2006). Writing. American University of Beiruit. Retrieved from http:/nadabs.tripod.com/ghaith-writing.html

Obioma, C. (2006). Verb related error in written English among secondary school students in Nsukka Education Zone. Unpublished Ph.D Thesis University of Nigeria Nsukka.

Odo, A. C. (2004). Factors influencing students' achievement in English language. Ebonyi State University. Unpublished M.Ed Dissertation.

Okonkwo, A. F. (2008). Problems in the implementation of the English language curriculum in the senior secondary schools in Ebonyi State. Unpublished M.Ed Dissertation. Ebonyi State University.

Radin, N. (1991). A comparison of behaviour material with four old year boys and girls in lower class families. E. E. Nicoby \& Jackline (ed) in the psychology of sex differences. California: Standard University Press. 
Table. 1 Mean Result of Students Based on Gender

\begin{tabular}{lcccccc}
\hline & \multicolumn{3}{c}{ MALES } & \multicolumn{4}{c}{ FEMALES } \\
Variables & No & X & SD & No & X & SD \\
Experimental & 49 & 43.08 & 12.48 & 46 & 40.86 & 15.14 \\
Control group & 49 & 31.24 & 14.26 & 47 & 34.91 & 10.67 \\
\hline
\end{tabular}

Table 2. ANCOVA Result Based on Gender Effects

\begin{tabular}{lccccccc}
\hline Source of Variation & $\begin{array}{c}\text { Sum of } \\
\text { Squares }\end{array}$ & Df & $\begin{array}{c}\text { Mean } \\
\text { squares }\end{array}$ & F & $\begin{array}{c}\text { Sig of } \\
\text { F }\end{array}$ & $\begin{array}{c}\text { F } \\
\text { critical }\end{array}$ \\
\hline Covariates & 4766.658 & 1 & 4766.658 & 27.891 & .000 & 3.84 \\
Pre-test & 4766.658 & 1 & 4766.658 & 27.891 & .000 & \\
Main effect & 189.534 & 1 & 189.534 & 1.109 & .294 & \\
Gender & 189.534 & 1 & 189.534 & 1.109 & .294 & \\
Explained & 4956.192 & 2 & 2478.096 & 14.500 & .000 & \\
Residual & 32129.557 & 188 & 170.902 & & & \\
Total & $\mathbf{3 7 0 8 5 . 7 4 9}$ & $\mathbf{1 9 0}$ & $\mathbf{1 9 5 . 1 8 8}$ & & & \\
\hline
\end{tabular}

Not significant at $\mathrm{p}<0.05$

\section{Copyright Disclaimer}

Copyright for this article is retained by the author(s), with first publication rights granted to the journal.

This is an open-access article distributed under the terms and conditions of the Creative Commons Attribution license (http://creativecommons.org/licenses/by/3.0/). 